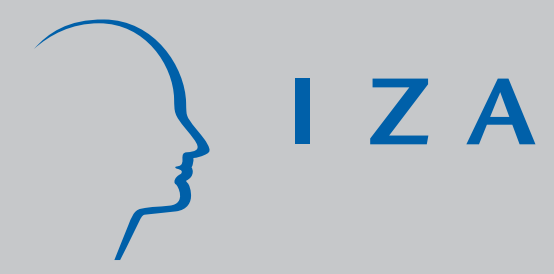

IZADP No. 2553

Wealth Accumulation and Distribution in Urban China

Xin Meng

J anuary 2007 


\title{
Wealth Accumulation and Distribution in Urban China
}

\author{
Xin Meng \\ Australian National University \\ and IZA \\ Discussion Paper No. 2553 \\ January 2007 \\ IZA \\ P.O. Box 7240 \\ 53072 Bonn \\ Germany \\ Phone: +49-228-3894-0 \\ Fax: +49-228-3894-180 \\ E-mail: iza@iza.org
}

\begin{abstract}
Any opinions expressed here are those of the author(s) and not those of the institute. Research disseminated by IZA may include views on policy, but the institute itself takes no institutional policy positions.

The Institute for the Study of Labor (IZA) in Bonn is a local and virtual international research center and a place of communication between science, politics and business. IZA is an independent nonprofit company supported by Deutsche Post World Net. The center is associated with the University of Bonn and offers a stimulating research environment through its research networks, research support, and visitors and doctoral programs. IZA engages in (i) original and internationally competitive research in all fields of labor economics, (ii) development of policy concepts, and (iii) dissemination of research results and concepts to the interested public.
\end{abstract}

IZA Discussion Papers often represent preliminary work and are circulated to encourage discussion. Citation of such a paper should account for its provisional character. A revised version may be available directly from the author. 


\section{ABSTRACT}

\section{Wealth Accumulation and Distribution in Urban China*}

Under socialism it was neither possible nor necessary to accumulate significant levels of personal wealth. The acceleration of economic reform in the last decade, however, has brought dramatic increases in income and investment opportunities. Reform has also reduced social protections provided by the state welfare system. In response to these changes, between 1995 and 2002, urban average real household net total wealth increased by 24 per cent per annum. There is a concern, however, that those accumulating wealth are the economic and political elites while those unable to accumulate wealth are the most vulnerable workers who are losing social protection. Using Chinese urban survey data of 1995, 1999, and 2002, this paper investigates this issue. It is found that households with above average income have accumulated more wealth than their poorer counterparts. In addition, a large proportion of this wealth accumulation may be from non-earned sources, such as buying larger and better housing at highly subsidized prices. Furthermore, party members and their children have benefited a great deal from this fast wealth accumulation process. Although at lower rates, the poor and vulnerable have also been able to accumulate wealth.

JEL Classification: D31, I30

Keywords: $\quad$ wealth, distribution, China

Corresponding author:

Xin Meng

Division of Economics

Research School of Pacific and Asian Studies

Australian National University

Canberra 0200

Australia

E-mail: Xin.Meng@anu.edu.au

\footnotetext{
* The author thanks Bob Gregory and Albert Park for helpful comments. Financial support from the Australian Research Council is highly appreciated.
} 


\section{Introduction}

Individual economic well being during old age and periods of unemployment and sickness is positively related to private wealth, especially in an economy where government has little ability to provide adequate social insurance. China is in the process of moving from state provision of all social welfare to a new system that relies heavily upon individual responsibility. In this new economic environment, accumulation and distribution of personal wealth will play an important role.

In the pre-reform era it was neither possible nor necessary to accumulate significant levels of personal wealth in urban China. Income was extremely low, making wealth accumulation difficult. Private property was seen as the root of capitalism and therefore forbidden. Neither a housing nor any other kind of capital market existed. Wealth accumulation was largely unnecessary because every urban resident was guaranteed a life-time job, a full pension, life-time free medical services, and free education for their children.

The acceleration of economic reform over the last decade has brought great change to the Chinese urban economy. A dramatic increase in income, and the establishment of housing and other kinds of financial markets, has made it possible for individuals to accumulate significant quantities of wealth quite quickly. In addition, the labor market and social security reform has narrowed the protection provided by the state welfare system making it necessary for individuals to accumulate wealth to protect themselves from adverse economic shocks and provide income for their old age. The result has been rapid wealth accumulation over a short period. For example, between 1995 and 2002 urban per capita real household net total wealth increased more than four fold. Nevertheless, there is a concern that those accumulating wealth are economic or political elites while those unable to accumulate wealth are the most vulnerable workers who are losing social protection. 
This paper utilizes three data sets which have direct measures of wealth, namely the Urban Household Income Distribution Surveys 1995, 1999, and 2002 (UHIDS95, UHIDS99, and UHIDS02), to investigate the following questions: How has wealth in urban China changed over this period? To what extent is wealth accumulation during this period associated with economic and social status? Are the poor, who are losing social protection, able to accumulate sufficient wealth to protect themselves?

The literature on wealth accumulation and distribution is mainly concentrated on developed and newly developed market economies (see Davies and Shorrocks, 2000 for a comprehensive review). While theoretical models have recently been developed for transitional economies (Ferreira, 1999; Alexeev, 1999), empirical studies of wealth accumulation and distribution during transition are rare. The few available studies on wealth accumulation and distribution in China mainly focus on the rural sector (Mckinley, 1993 and 1996) or use data for the period before the acceleration of urban economic reform. For example, Wang (1995) examines wealth distribution using data from the 1986 household survey. The only other study of household wealth in urban China using UHIDS95 data is currently in working-paper stage (Gustafesson, Li, and Wei, 2000).

Income and savings are major contributors to wealth accumulation and there is an extensive literature in both these fields, although the research is not usually linked directly to wealth accumulation and distribution. Many studies have examined income distribution in China (Knight and Song, 1991; Gustafsson and Li, 1997, 1998, 1999; Knight and Li, 1999; Kahn, Griffin, and Riskin, 1999; Yang, 2000; Khan and Riskin, 2000; Riskin, Zhao, and Li, 2000; Meng, 2004). One of the main findings is that income inequality increased during the decade before 1995 with regional variation being the major contributor. Meng (2004) shows that growth of income inequality has accelerated since then and unemployment associated with labour market reform has replaced regional dispersion as the major contributor. 
Other studies have investigated household saving (consumption) behavior in China (Jalan and Ravillion, 1996, 1998; Wang, 1995; Kraay, 2000; Meng, 2003; Modigliani and Cao 2004; and Yoo and Giles, 2006). A common finding is that over the reform period there has been a significant increase in the household saving rate. This paper links these two literature strands together and directly relates changes in income distribution and household savings to changes in wealth accumulation and distribution.

The paper is structured as follows. The next section provides institutional background on wealth accumulation in urban China. Section 3 presents basic statistics and graphics of the change in income and wealth distribution over the period. Section 4 discusses the determinants of wealth while concluding remarks are given in Section 5

\section{Background}

In most developed countries personal wealth is acquired from three main sources: lifetime saving, inheritance, and asset appreciation (Davies and Shorrocks, 2000). Browning and Lusardi (1996) cited Keynes' (1936) list of the nine motives for saving and suggested that the list seemed complete even from a 1990s' point of view. These motives are: the precautionary motive, the life-cycle motive, the intertemporal substitution motive, the improvement motive, the independence motive, the enterprise motive, the bequest motive, the avarice motive, and the downpayment motive. ${ }^{1}$

In urban China's pre-reform era (before 1978), three important factors prevented individual households from accumulating substantial personal wealth. First, income levels were low and barely enough for day-to-day living, let alone saving (Kraay, 2000). ${ }^{2}$ Thus, the intertemporal, improvement, and avarice motives were suppressed. Second, a social welfare system provided every urban individual with cradle-to-grave welfare, ensuring

\footnotetext{
${ }^{1}$ See Browning and Lusardi (1996) for a detailed explanation of each of these motives.

${ }^{2}$ As indicated in Kraay (2000), although saving rates were high before 1978, household savings only accounted for a small proportion of total saving. He shows that in 1979 the urban household saving rate was below 5 per cent (see Figure 4 in Kraay (2000)).
} 
life-time employment, full support for family medical expenses, fully funded old age pension, public accommodation at very low rental, and free children's schooling. Therefore, the need to save for precautionary, lifecycle, or bequest motives was absent. Third, the planned economy and lack of financial, housing and other important durable goods markets suppressed household downpayment and enterprize motives.

As economic reform proceeds, however, the importance of these three factors has gradually changed. Over the last twenty or so years, urban incomes have continued to increase rapidly. According to National Statistical Bureau survey data, urban annual household per capita real disposable income increased from 890 yuan in 1986 to 2328 yuan in 2002 (deflated by urban CPI), an annual increase of 6.2 per cent (National Bureau of Statistics (NBS), 2000 and 2003). In addition, business opportunities have flourished. While the proportion of urban workers employed in the private sector was 4.0 per cent in 1986, this ratio increased to 67 per cent in 2003 (NBS, 1989 and 2003), indicating the degree to which private individual investment opportunities have grown. More importantly, since the late 1980s, economic reform gradually swept away almost all aspects of the old social security system at the same time as state owned enterprizes began to lay off large numbers of workers. Old age, medical, and unemployment support has moved toward a system where individual responsibility is replacing state provision. Finally, although the development of capital markets has been slow, there has been large change in the provision of housing. Housing reform began with an increase in official rents before proceeding to allow government housing occupants to buy their own housing at a highly subsidized price, and then, finally moving on to a further opening up of the housing market. By 2002, most urban households had an expectation that they would purchase their own housing and the majority of urban households had already done so. All these factors have significantly increased households' precautionary, lifecycle, downpayments, and enterprize motives for accumulating wealth. 
Most of these changes, especially the large-scale reform in the social welfare system, have occurred only over the last ten years and. In response, household wealth accumulation in urban China has increased significantly. According to the Urban Household Income Distribution Surveys (UHIDS or CHIPs) 1995, 1999, and 2002, average household per capita real net total wealth in six survey provinces increased from 10,522 yuan in 1995 to 30,233 yuan in 1999, and further to 47,340 yuan in 2002, an increase of 24 per cent per annum over the whole period.

In addition to rapid growth in wealth accumulation, the process of wealth accumulation and distribution in urban China has a number of special features. The most relevant feature for this paper is the role of individual political status in the acquisition of wealth. Even though political status has always benefited high level government and party officials, economic reform has commercialized this status through the distribution of labor and non-labor income (Morduch and Sicular, 2000) and through the distribution of housing. For example, in the old system the size and quality of housing was determined by individual political power and occupational status. High level government officials and party members were often given better and larger housing to rent. The housing reform introduced in the early 1990s allowed those who were renting government housing to buy their occupied housing at a heavily subsidized price. The subsidy was also positively related to the seniority and political positions of household members. Thus, the acquisition of housing, which accounted for more than half of the average household wealth in 1999 and 2002, was affected by political status on two counts, the initial allocation of better housing and larger purchase price discounts.

Another special feature in personal wealth accumulation and distribution in urban China is the way in which inheritance takes place. The lack of wealth among the older generation means that the typical process of wealth inheritance observed in the west has been relatively unimportant in China. Children of important government or party 
officials, however, can easily profit from their parents' business networks and political connections. In addition, in the pre-reform era, children of individuals with high political power were normally able to acquire better housing which could subsequently be purchased at highly subsidized prices.

One of the main purposes of accumulating wealth is to protect individuals from the adverse effects of future uncertainties and old age poverty. Given the unique features of wealth accumulation in urban China there is a concern that those accumulating wealth are the economic or political elites while those unable to accumulate wealth are the most vulnerable workers who, at the same time, are losing social protection.

\section{$3 \quad$ Wealth accumulation and distribution}

The data used for the empirical work are taken from three Urban Household Income Distribution Surveys (UHIDS, or urban CHIP) conducted by the Institute of Economics, Chinese Academy of Social Sciences for the years 1995, 1999, and 2002. These are repeated cross-section surveys and do not track the same households over time. The three survey questionnaires were designed in a relatively consistent manner regarding income, expenditure, wealth and demographic information of household members and provide a good basis to study changes in wealth. The 1995 and 2002 surveys cover 11 provinces, whereas the 1999 survey covers 6 of the 11 provinces included in the other two surveys. To ensure consistency of comparison, only observations from the 6 provinces which are surveyed in all three years are included. ${ }^{3}$ Excluding missing values, the number of households included are 3777, 4449, and 3569 for the 1995, 1999, and 2002 surveys, respectively. Summary statistics are reported in Appendix A. ${ }^{4}$

\footnotetext{
${ }^{3}$ Note, however, that in the 1995 survey there were 33 cities included in the 6 provinces. In 1999, only 13 of these 33 cities were included, while in 2002, 30 of these 33 cities were included. It is, therefore, important to bear in mind that the inconsistency of the number of cities included in the sample of the 6 provinces may introduce some problems in the comparability of the sample over time.

${ }^{4}$ There is a concern about whether the proportion of the sample individuals who are party members is too high in the CHIPs' samples. This is, however, hard to verify as there are no official statistics available
} 
The surveys ask for detailed information on household financial, housing, productive and other assets, including household durables in value terms. In addition, the survey collects detailed debt information, including mortgage, borrowing for productive purposes, buying household durables, medical related debt, and other debt due to family difficulties. Regarding financial assets, seven detailed categories are included: term deposits, deposits in savings accounts, stocks, government bonds, personal lending, family productive use of personal financial wealth, and other investments. Based on these data a household net wealth measure is derived.

Table 1 reports summary statistics and measures of inequality of household income and different types of wealth for the survey years. Over the period 1995 to 2002, household per capita real income increased by 8.8 per cent per annum. ${ }^{5}$ The main income growth occurred during the 1995 to 1999 period with an annual growth rate of 10.1 per cent. Per capita net total wealth increased by 27 per cent per annum between 1995 and 1999 and 22 per cent between 1999 and 2002. Within total wealth, housing wealth grew fastest, at a rate of 50 per cent per annum in the first period and 19 per cent per annum in the second period. It is interesting to see that per capita real net wealth grew much faster than per capita real income in both periods. On average, per capita net wealth grew at an annual rate almost three times the annual growth rate of per capita income. Considering that

regarding the proportion of the population with urban household registration (where the sample is drawn from) who are party members. David Wall presented a figure on the total number of party members in China in 2006 as 71 million (Wall, 2006). Based on his figure and assuming the total number of party members in 2002 was 5 per cent less, 90 per cent of party members were in urban areas, and 78 per cent of urban population was aged 18 and above (based on 2000 census figure), the proportion of urban 18 and above population being party members should be 19.5 per cent. According to this figure, the data used in this study over sampled party members (the estimate in our data is 25.5, see Appendix A).

The only other data available to the author on urban party member rate is the 2000/2001 China Urban Labor Survey (CULS) on five large cities. The party member rates using this data (for comparable population, namely 18 and above) are presented in the second panel of Appendix A. The statistics show that the ratio of party members in the 1999 CHIPs sample is around 4 percentage points higher than that in the 2000 CULS sample, that is 25 per cent compared to 21 per cent. This difference may to some extent be due to difference in region and timing of the surveys.

${ }^{5}$ Note that the per capita household income presented in this paper does not include imputed rent value from owner-occupied housing. 
inheritance was negligible during this period, a faster increase in wealth than income suggests that either saving propensity increased significantly or a large proportion of wealth accumulation was from other non-saving sources. ${ }^{6}$ This issue will be examined later in this Section.

The differences between housing and net total wealth growth rates are mainly the result of the faster pace of housing reform during the 1995 to 1999 period. Table 2 shows that in 1988 (before the housing reform), less than 15 per cent of households owned their own home. In 1995, this had increased to 37 per cent, and to 64 per cent by 1999, 78 per cent by 2002. Most home ownership was obtained through subsidized purchase during the housing reform period and this may account for a large part of the non-saving wealth accumulation. The rate of increase in financial wealth (24 and 16 per cent per annum for the two periods, respectively) was also faster than the increase in real income per capita, indicating possible non-saving accumulation of financial wealth as well.

During this period, while income increased significantly, income inequality also increased. The Gini coefficient of household per capita real income increased from 36 per cent in 1995 to 38 per cent in 1999, and 40 per cent in 2002 (Table 1). Other inequality indices present the same picture. ${ }^{7}$ The situation with wealth distribution is less clear. Although similar to many developed countries where wealth distribution is more unequal than income distribution (Davies and Shorrocks, 2000), it is hard to compare changes in wealth inequality in urban China over time since different inequality indices provide different answers. For example, the Gini coefficient for per capita net total assets increased from 52 per cent in 1995 to 56 per cent in 1999 and then reduced to 50 per cent in 2002, whereas the coefficient of variation indicates a more unequal distribution in the 1995 data than in the 1999 and 2002 data. Similar mixed pictures exist in other asset measures.

\footnotetext{
${ }^{6}$ Including capital appreciation.

${ }^{7}$ This is consistent with findings from many other studies (see, for example, Gustafsson and Li, 1997, 1998, and 1999; Knight and Li, 1999; Yang, 1999; Khan and Riskin, 2000; Riskin, Zhao, and Li, 2001; Meng, 2004).
} 
Figure 1 presents the cumulative density functions (CDF) of real per capita total assets, net total assets, financial assets, and net housing assets. It shows that all types of assets increased over the period. In addition, in 1995 a large proportion of households had very limited asset accumulation, while over time more and more households exited the wealthless state and began to accumulate sizeable wealth. For example, in 1995, around 75 per cent of households possessed net housing wealth of less than Y5000. This ratio reduced to 44 per cent in 1999, and reduced further to 22 per cent in 2002 . Following Barrett and Donald (2002), Kolmogorov-Smirnov (KS) bootstrap tests of stochastic dominance are used to examine whether there is a statistical difference among the three CDFs. The KS type tests compare the objects at all points. The test results (test statistics and p-values) for first order stochastic dominance are reported in Table $3^{8}$ and they show that the 2002 cumulative distribution functions of all types of assets dominate the 1999 distributions, which in turn, dominate the 1995 distributions.

Lorenz curves for these assets are presented in Figure 2, which indicates that at the extreme ends of the distribution, there are signs of Lorenz-crossings in these distributions. In most cases the Lorenz-crossings occur between 1995 and 1999. Although wealth inequality for various assets, except housing, appear to be most unequal in 1999, Lorenzcrossings imply that the change in inequality measures of the assets presented here and in Table 1 is inconclusive (as discussed before) and it is not possible to compare wealth inequalities in a simple way over time. Nevertheless, if 1999 data are omitted, it is quite clear that inequality on total net wealth has reduced between 1995 and 2002. This is mainly due to the reduction of inequality in housing wealth. The substantial increase in housing ownership between 1995 (37 per cent) and 2002 (78 per cent) has meant that a large proportion of households' housing wealth increased from zero to a positive number.

The above analysis describes wealth distribution. It is also possible and interesting

\footnotetext{
${ }^{8}$ The second and third order stochastic dominants are also tested and they are all significant at the less than 1 per cent level.
} 
to examine the difference in wealth distribution and the speed of wealth accumulation between the income rich and the income poor. To do so, household per capita real income is ranked into percentiles and for each percentile average per capita net total wealth is calculated for the three years. Figure 3 presents these results as well as the growth rate for each percentile. The figure shows that real household per capita net total wealth increased for households in all percentiles of income, but the rate of increase was much faster for above average income households than for those below average. For example, between 1995 and 1999 the wealth growth rates for the bottom and top 10 percentile income households were 34 and 166 per cent, respectively, while between 1999 and 2002 the ratios were 111 and 346 per cent, respectively.

Furthermore, relative to income growth average wealth growth rates have been much faster (see Table 1), suggesting the existence of sizable non-saving wealth. To investigate whether the rich and the poor accumulated non-saving wealth at the same rate, the data on the base year's (1995) wealth level, the saving rates, and the annual growth rate in income between 1995 and 1999 and 1995 and 2002, ${ }^{9}$ are used to project what the wealth level would have been for each income percentile in year 1999 and 2002 had the net total wealth being accumulated only through savings. ${ }^{10}$ Projected wealth levels are then compared with the actual wealth levels. Figure 4 shows the result. It indicates that the projected wealth (pure saving wealth) is lower than actual wealth for households in all income percentiles. However, the amount of non-saving wealth is much higher for households with above average income levels than their poor counterparts. For example, in 1999 households with below 20 percentile income levels, on average, derived 18 per cent of wealth from non-saving sources, while for those with income levels above 80 percentiles

\footnotetext{
${ }^{9}$ Saving is calculated by subtracting household total expenditure from household total income.

${ }^{10}$ The projection is calculated as follows: $\widehat{W}_{T}=W_{1}+\sum_{n=1}^{n-T} s_{n} *(1+\dot{y})^{(n-1)} * Y_{n}$, where $\widehat{W}$ is projected wealth from saving alone, $W$ is the actual wealth level, $s$ is the saving rate, $\dot{y}$ is the income growth rate, and $Y$ is the actual income level.
} 
this ratio is 42 per cent. In 2002 the rich also received much more wealth from non-saving sources than the poor. These results suggest the rich might have been given more wealth than the poor in the form of direct wealth transfers, such as housing, or in the form of income, such as gifts.

Of course, if existing wealth appreciated at a very high rate it could be another explanation for the existence of sizable non-saving wealth. This, however, is unlikely to explain the major part of the difference between actual and predicted wealth levels. The type of wealth most likely to have appreciated is housing. According to the China National Bureau of Statistical (NBS, 1996, 2000, and 2003), the unit residential housing market selling price (per square meter) increased by 28 per cent on average for the six provinces studied in this paper over the period 1995 to 1999 and by 37 per cent from 1995 to $2002 .^{11}$ Taking into account the proportion of net housing wealth to net total wealth for each income percentile and each survey year, the effect of housing price (both official and survey data) appreciation on net total wealth is also projected. This is shown in Figure 4 as the two dotted lines and both are still much lower than the actual net total wealth levels.

In addition to the inequality of wealth distribution among high and low income households, households whose heads are party members accumulated more wealth than those whose heads are not party members. Table 4 shows that in 1995 households headed by

\footnotetext{
${ }^{11}$ The data on residential housing market selling prices for each of the six provinces in each of the survey years are listed in Appendix B. These data are obtained from Table 5-35 on page 188, the China Statistical Yearbook, 1996; Table 6-44 on page 225 of the China Statistical Yearbook, 2000; and Table 6-45 on page 245, the China Statistical Yearbook, 2003. It is possible that these data underestimate housing price appreciation during this period but they are the only official data available. Appendix B also lists household self-evaluated market value per square meter of owner occupied housing for 1999 and 2002 surveys. These self-assessed data indicate a similar level of unit housing price but much lower housing price increase between 1999 and 2002. On average, the self-assessed per square meter owner occupied market housing price reduced by 2.2 per cent between 1999 and 2002 .

Note that the 1995 survey did not ask for the self-evaluated market value of owner occupied housing but only the total housing wealth information. The information on living area, however, is on owner occupied housing, and hence, it is not possible to derive a comparable variable to those derived from the 1999 and 2002 data.
} 
party members had 2,552 yuan more net total wealth per capita than those headed by non-party members. There is a 24 per cent difference. This difference is 35 and 29 per cent in 1999 and 2002, respectively.

The above summary statistics indicate that household wealth has grown rapidly during the period of study, and in particular, between 1995 and 1999. This occurred not only to high income but also to low income households. However, even though wealth increased for both rich and poor, the rich and politically elite gained the most of non-saving wealth.

\section{Determinants of wealth}

\subsection{Results from the wealth equation}

To further investigate the determinants of wealth, the following reduced-form wealth equation is estimated:

$$
W_{i}=\alpha+X_{i}^{\prime} \beta+u_{i}
$$

where $X_{i}$ is a vector of explanatory variables, including age of household head, ${ }^{12}$ gender, years of schooling of household head and spouse, political affiliations of household head, spouse, and father of the household head (whether they are party members or not), number of working age household members (aged 16 to 65), and household location of residence. These variables mainly proxy households' permanent income and demographic nature, as well as political status.

Note that there are zero and negative values of various wealth measures. ${ }^{13}$ Following recent studies on wealth holding (see, for example, Kapteyn, Alessie, and Lusardi, 1999, Carroll, Dynan, and Krane, 2003, and Pence, 2004 ), inverse hyperbolic sine transforma-

\footnotetext{
${ }^{12}$ Ages of the household head and spouse are highly correlated. Hence, only the age of the household head is included in the regression.

${ }^{13}$ The proportion of households with zero or negative total assets, net total assets, and financial assets is quite small, especially in the later years. The main source of the negative and zero wealth is net housing wealth, though over time the proportion reduces dramatically (See Table 1).
} 
tions of different wealth measures are used as the dependent variables. Thus, equation (1) may be written as:

$$
\sinh ^{-1}\left(W_{i}\right)=\widetilde{\alpha}+X_{i}^{\prime} \widetilde{\beta}+\epsilon_{i}
$$

The inverse hyperbolic sine transformation is defined as: $g\left(W_{i}\right)=\sinh ^{-1}\left(\theta W_{i}\right) / \theta=$ $\ln \left(\theta W_{i}+\left(\theta^{2} W_{i}^{2}+1\right)^{1 / 2} / \theta\right.$, where $\theta$ is a damping parameter. ${ }^{14}$ To interpret the results the marginal effect for each variable is calculated and the calculation is based on the following formula: $\partial w / \partial x=\beta\left((\theta w)^{2}+1\right)^{1 / 2}$, where the first term is the estimated coefficient, and the second term is $\partial w / \partial \sinh ^{-1}(w)$.

Equation (2) is estimated using the 1995, 1999, and 2002 UHIDS data. The selected marginal effects and bootstrapped standard errors for net total wealth, financial wealth and net housing wealth are reported in Table $5 .^{15}$ Note that the variable indicating whether the father of the household head is a party member or not is not available from the 1995 data. To facilitate comparison across the three surveys, results from equation (2), both with and without this variable, are presented for the 1999 and 2002 data.

The top panel of Table 5 presents the results from net total wealth equation. The first important finding is a significant increase in the effects of income related variables on wealth over the three survey years. For example, evaluated at median wealth, the marginal effect of one more year of household head schooling increases household net total wealth by 296, 2498, and 3831 yuan and the marginal effect for one year of spouse schooling is 156, 1375, and 3214 yuan for the three survey years, respectively. These effects added together (one more year of education for household head and spouse) increase

\footnotetext{
${ }^{14}$ This study uses 0.00005 for $\theta$ as it produces a closer approximation to a normal distribution in the data (see Appendix $\mathrm{C}$ for a plot of residuals).

${ }^{15}$ The marginal effects are evaluated at the median level of wealth. Full results of estimated coefficients and marginal effects are available upon request from the author. Summary statistics of all variables used in these estimations are reported in Appendix A. Note also, as age in the 1995 and 1999 data has a non-linear relationship with wealth, a squared term is included. The Marginal Effect for age, therefore, is derived as $\partial w / \partial x=\left(\beta_{\text {age }}+2 \beta_{\text {Sage }} *\right.$ Age $) *\left((\theta w)^{2}+1\right)^{1 / 2}$.
} 
median net total wealth by 2.1 per cent in 1995 and 7.1 and 6.8 per cent in 1999 and 2002, respectively. Similarly, marginal effects for other income related variables, such as age and number of working aged members in the household, also increase significantly over the period.

Another finding is that the effect of age on wealth in urban China differs from the lifecycle model, which predicts that individuals accumulate wealth until retirement and after that they begin to consume wealth. Thus, an inverse U-shaped relationship between wealth and age should be observed with the peak level of wealth around the retirement age. The estimations indicate that for 1995 and 1999, the net total wealth levels do exhibit an inverse U-shape relationship with the age of household head but they peak at age 52 in the 1995 survey and 76 in the 1999 survey. In 2002, the age wealth relationship is linear, continuously increasing with age (See Figure 5). ${ }^{16}$ This unusual shape may be due to the housing reform. The privatization of housing has made everyone wealthier, and the old, on average, have gained more, since they previously occupied larger and better located housing than the young. This conjecture will be confirmed later in Table 6.

The relationship between gender and wealth is also interesting. Apart from the 1995 survey, female headed households seem to have accumulated more wealth in 1999 and 2002. Since in general, women earn less than men, this finding is quite unusual. Nevertheless, it is also observed that female headed households are less likely to be poor in urban China (Meng, Gregory, and Wan, 2006). Note that in the 1995, 1999, and 2002 surveys female headed households account for 31, 30, and 28 per cent of the total sample, respectively (see Appendix A).

Perhaps, the most important finding from the net total wealth equation is that wealth is positively associated with party membership of the household head, the spouse, and

\footnotetext{
${ }^{16}$ Note that to make the graph easier to view, it is assumed that for each year the curve starts from zero wealth, ie. no constant term is added to the projection.
} 
the father of the household head. The effect of the household heads' and spouses' party member status is first examined. In 1995, if the household head and spouse were party members, household net total wealth was around 2,927 and 4019 yuan higher, respectively. These figures accounted for 14 and 19 per cent of the median net total wealth. In 1999, the effect of party member status for head and spouse increased to 13,819 and 9677 yuan, respectively, and accounted for 25 and 18 per cent of the median net total wealth in that year. In 2002, the effects were 17,463 and 16,781 yuan, accounting for 17 and 16 per cent of the median net total wealth. If both the head and spouse were party members, their net total wealth was around 32,43 , and 33 per cent higher than a household without a head and spouse being party members in 1995, 1999, and 2002, respectively. To put this into context, the effects of household head and spouse party member status in the three survey years are equivalent to the effects of 15.4, 6.1 and 4.9 years of schooling on net total wealth in 1995, 1999, and 2002, respectively. These are very large effects.

If the father of the household head is a party member, it brings additional wealth in the two surveys where the variable is available. In 1999, with a father of the household head being a party member, the household gained an additional 5569 yuan, accounting for 10.1 per cent of median net total wealth, while the figure in 2002 was 10540 yuan, accounting for 10.0 per cent of the median wealth.

The results from the financial wealth and housing wealth equations are reported in the middle and bottom panels of Table 5 , respectively. These results are very similar to those of the net total wealth equation. Most importantly, party memberships of household members are positively and statistically significantly associated with financial and housing wealth in almost all survey years with the exception being that spouse party membership has no statistically significant effect on housing wealth in 1995. In addition, the effect of education on both financial and housing wealth increased over time. Some exceptions, however, are observed. For example, many variables are statistically insignificant, and 
some have the wrong signs in the housing wealth equation for the 1995 data. In particular, both the effects of education level of household heads and spouses are negative. This may be due to the lack of development of the housing market and the lack of housing ownership in that year.

\subsection{Further understanding of the effect of party status}

The above analysis indicates that the estimated effect of party member status on wealth accumulation is very important. How should these substantial party member premia be interpreted? Many other studies have also found an association between party membership and economic outcomes. For example, party members in China earn significantly more than non-party members (Morduch and Sicular, 2000; Appleton, Song, and Xia, 2005). Using the same data, the same sample, and controlling for the same set of explanatory variables it is found that in 1995 if the head or spouse of a household is a party member, household per capita income is 7.6 and 11.9 per cent higher than if the head/spouse is not a party member, respectively. These ratios are 19.4 and 15.9 per cent in 1999 and 11.4 and 14.5 per cent in 2002. ${ }^{17}$ Two common interpretations of the party member premium are: (1) Individuals with higher ability are more likely to join the party, and also to achieve better economic outcomes such as a higher income. As a result, they may accumulate more wealth. (2) Because of party members' political status they can acquire more economic resources and therefore can accumulate more wealth. ${ }^{18}$ The

\footnotetext{
${ }^{17} \mathrm{Li}$, Liu, Zhang, and Ma (2006) using data for 725 twin pairs find that there is no within-twin impact of party membership on the variation of earnings. Nevertheless they conclude that: "If the within-family externality interpretation is true, then Party membership will be important in terms of earnings for both Party members themselves and their family members."

${ }^{18}$ There may be another interpretation: As the Chinese economy became privatized, it was non-party members who moved out of the public sector first. Because housing subsidies were only applicable to the public sector, the observed party member effect may be an effect of selection into different sectors of employment by party and non-party individuals. To examine this issue the ratio is calculated of the net total wealth for households whose heads are party members, and those whose heads are not, only for the sample of households whose heads are employed in the state sector. It is found that within the state sector party member households have 27.4, 33.3, and 22.2 per cent more wealth than non-party member households in the three survey years, respectively. Whereas for other sectors (collective and private) the ratios are 29.0, 44.3, and 39.8, respectively. These data, which are available upon request, suggest that
} 
first interpretation implies that party membership is a proxy for individual unobserved ability and the effect of party membership on wealth, therefore, is related to the return to unobserved human capital. The second interpretation suggests that the return to party membership is a pure political rent. In reality, both factors are probably at work and it is difficult to disentangle them. Given this difficulty it is best to interpret the estimated party membership premia as a combination of a reward to party members' unobserved abilities and to their political power.

Nevertheless, it may still be useful to explore further the ways through which party members accumulate extra wealth relative to non-party members. This subsection, in particular, examines how party members acquire extra housing wealth. This is important because housing wealth accounted for more than half average total wealth in both 1999 and 2002 and is primarily responsible for fast wealth growth.

The following two questions are explored: 1. Did party members possess larger and better housing before housing reforms began? 2. During housing reform did party members receive higher price subsidies?

The UHIDS surveys have information on household housing conditions, including size of the house, type of bathroom, kitchen, heating and cooking facilities, and location. The survey also asks individuals the price at which they purchased the house and if they were to buy the house from the market place now what the current price would be. This information enable me to explore the two questions posed above.

To address the first question, the housing size and quality are regressed against a vector of household characteristics and household head and spouse' personal characteristics, including party membership status for the years 1988 and 1995 when the housing reform

the observed positive association between party membership and wealth accumulation is not an artefact of more party members being employed in the state sector where the housing subsidy is more important. It is shown later that within the state sector, before housing privatization, party members were allocated larger and better housing and that during the privatization process party members also enjoyed higher subsidies. 
had not yet or had only just begun. ${ }^{19}$ Note that the variable indicating housing quality is an index generated from whether a house has both bathroom and toilet, central gas cooking facility, central heating, and own kitchen. These equations are estimated for the sample of households renting from the government (state owned work units) at the time of the survey. The estimated results are reported in the first four columns of Table 6 . It is observed that controlling for household and individual characteristics, party members possess larger houses. In 1988 the household head and spouse being a party member is associated with 6.2 per cent and 8.6 per cent more housing, respectively. In 1995, the ratios are 7.1 and 5.7 per cent, respectively. With regard to housing quality, it is observed that party membership of both household heads and spouses has a positive effect, though only the effect of the spouses' party membership is statistically significant.

Next the question of whether party members were given a higher price subsidy when they purchased the house during the housing reform is examined. To investigate this issue, the 1999 and 2002 data are used when the housing market was well developed. In the surveys, respondents were asked to report the total amount paid to buy their current housing, and what they estimated the price would have been had they bought the house from the market place. The difference between the two should be a measure of the purchase price subsidy, after controlling for the timing difference between the point of purchase and the point of market price evaluation. Note that as the market price is estimated by respondents, the data are quite noisy and some respondents did not report a market value. To minimize measurement error in evaluated market price and to fill in missing values, a market value equation is first estimated using housing size, whether there is a central heating, central gas cooking, both bathroom and toilet, own kitchen, the location, the type of housing, and region as explanatory variables. After excluding a few

\footnotetext{
${ }^{19}$ The UHIDS survey was also conducted in 1988. Due to lack of wealth information, the 1988 data are not used in this paper. However, 1988 survey does include housing condition information, which will be utilized here.
} 
outliers, the adjusted $R^{2}$ for the 1999 data is 0.43 and for 2002 it is 0.32 (see Appendix D for full results).

Using the estimated coefficients the market value of the housing is then predicted for each household. The purchase price subsidy is obtained by taking the difference between the predicted market value and the purchase value of the house. The results from the log purchase price subsidy equation for a sample of households who bought the house during the housing reform period are reported in columns 5 and 6 of Table 6 . In addition to the same explanatory variables used in the housing size and quality equations in Table 6 , variables indicating years since the household bought the house and its squared term are also included to control for price appreciation since the household bought the house. In 1999 a household head being managerial staff is positively and statistically significantly associated with a higher purchasing price subsidy and larger households gain a higher subsidy. In 2002, household head and spouse' education is also associated with a higher subsidy. More importantly, both household head and spouse' party membership are associated with a higher subsidy in both years. The effect of household head and spouse party membership in 1999 is 13.4 and 9.1 per cent, respectively, while in 2002, it is 9.8 and 6.8 per cent, respectively.

The above analysis indicates that in the pre-housing reform period, party members were rewarded with larger and better housing relative to their non-party member counterparts. Furthermore, during the housing reform period, party members received higher price subsidies. Although it is impossible to examine whether and to what extent this unequal distribution of housing and purchase price subsidy between party members and non-party members is a reflection of a reward to party members' unobservable ability, the results clearly indicate that privatization of the public housing gave party members a sudden windfall of private housing wealth. 


\section{Conclusions}

Personal per capita net total wealth in urban China has increased at an annual rate of 24 per cent in real terms over the period 1995 to 2002. This is an unprecedented change. This paper has documented and analyzed this change. The following findings are of particular interest.

First, while both real income and real wealth increased rapidly, the rate of growth of wealth was much faster than the growth in real income. The analysis indicates that wealth distribution became more equal in 2002 than in 1995.

Second, a large proportion of the increase in wealth accumulation may come from non-saving channels.

Third, although households at each income percentile have experienced increases in wealth and increases in non-saving wealth, the increase is larger for the high income group than for the low income group.

Fourth, wealth accumulation in China differs from the lifecycle model prediction. Household wealth is almost linearly associated with household heads' age in recent years. This unusual shape of the age-wealth profile is, perhaps, related to housing reform as the aged normally had larger housing and were able to benefit more from the housing reform.

Fifth, party members and their children have done particularly well in accumulating wealth. Relative to the median of net total wealth, those households, where both head and spouse are party members, accumulate 31 to 43 per cent more net total wealth in the three survey years. Having a household head whose father is a party member contributes an additional 10 per cent increment in net total wealth for 1999 and 2002, respectively. Note that, due to the inability to find good instruments, the estimated party membership effect is a combination of the reward to party members' unobservable ability and to their political power.

Finally, one reason why party members have more wealth than their non-party mem- 
ber counterparts is the larger and better housing they possessed prior to housing reform and the higher purchasing price subsidy they received during the housing reform. Of course, rewarding party members with better and larger housing and higher housing price subsidy can also be an ability related.

It is important to bear in mind that this paper only studies the private accumulation of wealth and wealth distribution among households. The issue of transfer of wealth (especially housing wealth) from the state to households and the tax implications of such transfers, although important in the context of China, are not investigated in this paper. 


\section{References}

[1] Alexeev, Michael, 1999. "The Effect of Privatization on Wealth Distribution in Russia." Economics of Transition, 7 (2): 449-465.

[2] Appleton, S., Song, L., and Xia, Q., 2005, "Has China acrossed the river? The evaluation of wage structure in urban China during reform and retrenchment", Journal of Comparative Economics, 33(4), pp.644-663.

[3] Barrett, Garry and Donald, Stephen G., 2003. "Consistent Tests for Stochastic Dominance." Econometrica, 71(1): 71-104.

[4] Browning, Martin and Lusardi, Annamaria, 1996. "Household Saving: Micro Theories and Micro Facts", Journal of Economic Literature, 34(4): 1797-1855.

[5] Carroll, Christopher D., Dynan, Karen E., and Krane, Spencer D., 2003. "Unemployment Risk and Precautionary Wealth: Evidence from Households' Balance Sheets." Review of Economics and Statistics, 85(3): 586-604.

[6] Davies, James B. and Shorrocks, Anthony F., 2000. "The Distribution of Wealth." in Anthony Atkinson and Francois Bourguignon (eds), Handbook of Income Distribution, Volume 1, Amsterdam: North Holland ELSEVIER.

[7] Ferreira, Francisco H. G., 1999. "Economic Transition and the Distributions of Income and Wealth." Economics of Transition, 7(2): 377-410.

[8] Giles, John and Yoo, Kyeongwon, 2006. "Precautionary Behavior, Migrant Networks and Household Consumption Decisions: An Empirical Analysis Using Household Panel Data from Rural China." Review of Economics and Statistics, forthcoming.

[9] Gustafsson, Bjorn and Li, Shi, 1997. "Types of Income and Inequality in China at the End of the 1980s." Review of Income and Wealth, 43(2): 211-226.

[10] Gustafsson, Bjorn and Li, Shi, 1999. "A More Unequal China? Aspects of Inequality in the Distribution of Equivalent Income", unpublished manuscript.

[11] Gustafsson, Bjorn, Li, Shi, and Wei, Zhong, 2000. "Household wealth in urban China 
in 1995", mimeo

[12] Jalan, Jvotsna and Ravallion, Martin, 1996. "Consumption insurance and saving behaviour in rural China", Manuscript, World Bank.

[13] Jalan, Jvotsna and Ravallion, Martin, 1998. "Precautionary Wealth in Rural China." Manuscript, World Bank.

[14] Kapteyn, Arie, Alessie, Rob, and Lusardi, Annamaria, 1999. "Explaining the Wealth Holdings of Different Cohorts: Productivity Growth and Social Security." Serie Research Memoranda, 1999-38.

[15] Keynes, J. Maynard, 1936. The General Theory of Employment, Interest, and Money, London: MacMillan.

[16] Khan, Azizur R., Griffin, Keith, and Riskin, Carl, 1999. "Income Distribution in Urban China During the Period of Economic Reform and Globalization." American Economic Review, 89(2): 296-300.

[17] Khan, Azizur R. and Riskin, Carl, 2000. Inequality and Poverty in China in the Age of Globalization, Oxford: Oxford University Press.

[18] Knight, John and Li, Shi, 1999. "Fiscal Decentralization, Redistribution and Reform in China." Oxford Development Studies, 27(1): 5-32.

[19] Knight, John and Song, Lina, 1991. "The Determinants of Urban Income Inequality in China." Oxford Bulletin of Economics and Statistics, 53(2): 123-154.

[20] Kraay, Aart, 2000, "Household Saving in China", World Bank Economic Review, 14(3), pp.545-570.

[21] Li, H., Liu, P., Zhang, J., and Ma, N., "Economic return to communist party membership: evidence from urban Chinese twins", Economic Journal, forthcoming.

[22] McKinley, Terry, 1993, "The Distribution of Wealth in Rural China." in Keith Griffin and Zhao Renwei, (eds.), The Distribution of Income in China, pp. 116-34, London: Macmillan Press. 
[23] McKinley, Terry, 1996, The Distribution of Wealth in Rural China, Armonk, New York: M.E. Sharpe.

[24] Meng, Xin, 2003. "Unemployment, Consumption Smoothing, and Precautionary Saving in Urban China." Journal of Comparative Economics, 31(3): 465-485.

[25] Meng, Xin, 2004. "Economic Restructuring and Income Inequality in Urban China." Review of Income and Wealth, 50(3): 357-379.

[26] Meng, X., Gregory, R.G., and Wan, G., 2006, "China urban poverty and its contributing factors, 1986-2000", memo, Australian National University.

[27] Modigliani, Franco and Cao, Shi Larry, 2004. "The Chinese Saving Puzzle and the Life-Cycle Hypothesis." Journal of Economic Literature, XLII(March, 2004): 145170.

[28] Morduch, Jonathan and Sicular, Terry, 2000. "Politics, Growth, and Inequality in Rural China: Does It Pay to Join the Party?" Journal of Public Economics, 77(3): $331-56$.

[29] National Statistical Bureau of China, 1989, 1996, 2000, and 2003, China Statistical Yearbook, 1989, 1996, 2000 and 2003, Beijing: China Statistical Publishing House.

[30] Pence, Karen M., 2004. "Estimating the Effect of Tax Incentives on Saving: the Importance of Functional Form." Unpublished manuscript.

[31] Riskin, Carl, Zhao, Renwei, and Li, Shi, 2000. China's Retreat from Equality: Income Distribution and Economic Transition. Armonk, N.Y.: M.E. Sharpe.

[32] Wang, Yan, 1995. "Permanent Income and Wealth Accumulation: A Cross-Sectional Study of Chinese Urban and Rural Households." Economic Development and Cultural Change, 43(3): 522-550.

[33] Wall, David, 2006, "It pays to join China's CCP", Japan Times (August 28, 2006).

[34] Yang, Dennis T, 1999. "Urban-Biased Policies and Rising Income Inequality in China." American Economic Review, 89(2): 306-310. 
Table 1: Summary statistics and inequality measures of real per capita income and wealth, 1995, 1999, and 2002

\begin{tabular}{|c|c|c|c|c|c|}
\hline $1995(1995=100)$ & Per capita income & Per capita total wealth & $\begin{array}{l}\text { Per capita net total } \\
\text { wealth }\end{array}$ & $\begin{array}{l}\text { Per capita financial } \\
\text { wealth }\end{array}$ & $\begin{array}{l}\text { Per capita net housing } \\
\text { wealth }\end{array}$ \\
\hline Std. Dev. & 1409 & 40467 & 14200 & 6806 & 9425 \\
\hline Coefficient of variation & 0.83 & 1.26 & 1.33 & 1.74 & 2.65 \\
\hline Gini coefficient & 0.36 & 0.50 & 0.52 & 0.60 & 0.88 \\
\hline$\%$ of households with negative or zero wealth & & 0.05 & 0.06 & 0.13 & 0.70 \\
\hline \multicolumn{6}{|l|}{$1999(1995=100)$} \\
\hline Coefficient of variation & 0.84 & 1.13 & 1.26 & 1.56 & 1.66 \\
\hline Standard deviation of logs & 0.71 & 1.31 & 1.29 & 1.33 & 0.94 \\
\hline Gini coefficient & 0.38 & 0.53 & 0.56 & 0.64 & 0.68 \\
\hline$\%$ of households with negative or zero wealth & & 0.02 & 0.04 & 0.17 & 0.39 \\
\hline \multicolumn{6}{|l|}{$2002(1995=100)$} \\
\hline Mean & 3068 & 151735 & 48621 & 14437 & 29823 \\
\hline Annual growth rate 95-99 (\%) & 10.05 & 26.71 & 29.95 & 23.86 & 49.60 \\
\hline Annual growth rate 99-02 (\%) & 7.04 & 22.40 & 17.02 & 16.28 & 18.79 \\
\hline Annual growth rate 95-02 (\%) & 8.75 & 24.85 & 24.24 & 20.55 & 35.52 \\
\hline
\end{tabular}


Table 2: Housing ownership

\begin{tabular}{llcll}
\hline \hline & & Rented & & Owner occupied \\
1988 & Freq. & $\%$ & Freq. & $\%$ \\
1995 & 3578 & 85.11 & 626 & 14.89 \\
1999 & 2436 & 63.31 & 1412 & 36.69 \\
2002 & 1621 & 36.17 & 2860 & 63.83 \\
\hline \hline
\end{tabular}

Sources: Household Income Distribution Surveys, 1988, 1995, 1999, and 2002, Institute of Economics, the Chinese Academy of Social Sciences.

Table 3: First order stochastic dominance in different types of wealth

\begin{tabular}{|c|c|c|}
\hline & 1999 versus 1995 & 2002 versus 1999 \\
\hline Total assets & $\begin{array}{l}17.31 \\
(0.00)\end{array}$ & $\begin{array}{l}10.33 \\
(0.00)\end{array}$ \\
\hline Net total assets & $\begin{array}{l}16.84 \\
(0.00)\end{array}$ & $\begin{array}{l}10.21 \\
(0.00)\end{array}$ \\
\hline Financial assets & $\begin{array}{l}11.74 \\
(0.00)\end{array}$ & $\begin{array}{c}6.36 \\
(0.00)\end{array}$ \\
\hline Net housing assets & $\begin{array}{l}17.12 \\
(0.00)\end{array}$ & $\begin{array}{l}10.88 \\
(0.00)\end{array}$ \\
\hline
\end{tabular}

Note: Figures in parentheses are p-values.

Table 4: Difference in per capita net wealth between party and non-party member

\begin{tabular}{lllll}
\hline \hline & $\begin{array}{l}\text { Non-party member } \\
\text { headed HH (1) }\end{array}$ & $\begin{array}{l}\text { Party member } \\
\text { headed HH (2) }\end{array}$ & $\begin{array}{l}\text { Difference (3): } \\
(2)-(1)\end{array}$ & $\begin{array}{l}\text { (3) as \% of average } \\
\text { per capita net total } \\
\text { wealth }\end{array}$ \\
1995 & 9643 & 12195 & 2552 & 24.25 \\
& $(13474)$ & $(15044)$ & $(4.96)$ & 35.16 \\
& 26225 & 36853 & 10629 & $(8.61)$ \\
2002 & $(32261)$ & $(41126)$ & 13651 & 28.84 \\
\end{tabular}

Note: Figures in parentheses in columns (1) and (2) are standard diviations, and in column (3) are t-ratios. 
Table 5: Determinants of household wealth (marginal effects evaluated at median wealth)

\begin{tabular}{|c|c|c|c|c|c|}
\hline \multirow[t]{2}{*}{ Net Total Wealth } & \multirow{2}{*}{$\begin{array}{l}1995 \text { Survey Data } \\
\text { Model } 1\end{array}$} & \multicolumn{2}{|c|}{1999 Survey Data } & \multicolumn{2}{|c|}{2002 Survey Data } \\
\hline & & Model 1 & Model 2 & Model 1 & Model 2 \\
\hline \multirow[t]{2}{*}{$\mathrm{HH}$ head party member } & $\overline{2927^{* \star \star}}$ & $13819^{\star \star \star}$ & $13310^{* * *}$ & $17463^{* * *}$ & $16876^{* \star \star}$ \\
\hline & $(716)$ & $(1859)$ & $(1824)$ & $(3404)$ & $(3257)$ \\
\hline \multirow[t]{2}{*}{ Spouse party member } & $4019^{* \star *}$ & $9677^{\star \star \star}$ & $9407^{\star * \star}$ & $16781^{* \star *}$ & $16170^{* \star *}$ \\
\hline & $(865)$ & (2358) & $(2306)$ & $(3983)$ & $(3828)$ \\
\hline \multirow[t]{2}{*}{ Father party member } & & & $5569^{* \star *}$ & & $10540^{* * *}$ \\
\hline & & & (1939) & & $(3561)$ \\
\hline \multirow[t]{2}{*}{$\mathrm{HH}$ head years of schooling } & $296^{* * *}$ & $2498^{\star * *}$ & $2475^{* * *}$ & $3831^{\star \star \star}$ & $3736^{* \star *}$ \\
\hline & $(114)$ & $(299)$ & $(302)$ & $(529)$ & $(498)$ \\
\hline \multirow[t]{2}{*}{ Spouse years of schooling } & 156 & $1375^{* \star *}$ & $1364^{* \star *}$ & $3214^{\star \star \star}$ & $3164^{* \star *}$ \\
\hline & (95) & $(251)$ & $(244)$ & $(468)$ & $(479)$ \\
\hline \multirow[t]{2}{*}{$\mathrm{HH}$ head age } & 64 & $582^{* * *}$ & $661^{\star \star \star}$ & $1075^{\star \star \star}$ & $1188^{\star \star \star}$ \\
\hline & $(98)$ & $(210)$ & $(219)$ & $(151)$ & $(158)$ \\
\hline \multirow[t]{2}{*}{$\mathrm{HH}$ head gender } & $1824^{\star \star \star}$ & $-5131^{\star \star \star}$ & $-4985^{\star \star \star}$ & $-6798^{* *}$ & $-6517^{* *}$ \\
\hline & $(678)$ & $(1891)$ & $(1843)$ & $(3444)$ & $(3384)$ \\
\hline \multirow[t]{2}{*}{ Number of adult memb (16-65) } & $2716^{\star \star \star}$ & $4989^{\star \star \star}$ & $5128^{\star \star \star}$ & $11979^{\star \star \star}$ & $12195^{* \star *}$ \\
\hline & $(417)$ & $(1096)$ & $(1096)$ & $(2025)$ & $(1892)$ \\
\hline \multicolumn{6}{|c|}{ Effect of party status as proportion of median wealth } \\
\hline total effect & 0.32 & 0.43 & 0.52 & 0.33 & 0.42 \\
\hline $\mathrm{HH}$ head party member effect & 0.14 & 0.25 & 0.24 & 0.17 & 0.16 \\
\hline Spouse party member effect & 0.19 & 0.18 & 0.17 & 0.16 & 0.15 \\
\hline Father party member effect & & & 0.10 & & 0.10 \\
\hline Adjusted $\mathrm{R}^{2}$ & 0.11 & 0.14 & 0.14 & 0.25 & 0.25 \\
\hline Number of observations & 3777 & 4449 & 4449 & 3569 & 3569 \\
\hline \multirow{3}{*}{$\begin{array}{l}\text { Financial Wealth } \\
\mathrm{HH} \text { head party member }\end{array}$} & 1995 Survey Data & 1999 Sur & & 2002 Sur & \\
\hline & $\overline{1161^{* * *}}$ & $2881^{* \star *}$ & $2752^{\star \star \star}$ & $4190^{* \star \star}$ & $4083^{\star \star \star}$ \\
\hline & $(350)$ & $(565)$ & $(550)$ & $(876)$ & $(893)$ \\
\hline \multirow[t]{2}{*}{ Spouse party member } & $2395^{\star \star *}$ & $1164^{*}$ & 1095 & $4224^{\star \star \star}$ & $4112^{* \star *}$ \\
\hline & $(466)$ & $(691)$ & $(706)$ & $(1121)$ & $(1143)$ \\
\hline Father party member & & & $1415^{* \star *}$ & & $1927^{\star \star}$ \\
\hline & & & $(560)$ & & $(967)$ \\
\hline $\mathrm{HH}$ head years of schooling & $330^{\star * *}$ & $658^{\star \star *}$ & $652^{\star \star \star}$ & $990^{\star * \star}$ & $973^{* \star *}$ \\
\hline & $(57)$ & $(87)$ & (89) & $(137)$ & $(138)$ \\
\hline Spouse years of schooling & $162^{\star \star \star}$ & $527^{\star \star \star}$ & $524^{* \star *}$ & $636^{\star \star *}$ & $627^{\star \star \star}$ \\
\hline & $(50)$ & $(70)$ & $(69)$ & $(118)$ & $(123)$ \\
\hline $\mathrm{HH}$ head age & 109 & 177 & $197^{*}$ & $122^{\star \star \star}$ & $143^{* \star \star}$ \\
\hline & (69) & $(112)$ & $(105)$ & $(38)$ & $(40)$ \\
\hline $\mathrm{HH}$ head gender & 20 & $-1803^{\star \star \star}$ & $-1766^{\star \star \star}$ & $-3271^{\star \star *}$ & $-3220^{\star \star \star}$ \\
\hline & $(319)$ & $(528)$ & $(546)$ & $(897)$ & $(908)$ \\
\hline Number of adult memb (16-65) & $685^{\star \star *}$ & $1093^{* * *}$ & $1128^{* * *}$ & $3338^{* * *}$ & $3377^{* * *}$ \\
\hline & $(201)$ & (335) & (332) & $(523)$ & $(509)$ \\
\hline Adjusted $\mathrm{R}^{2}$ & 0.14 & 0.18 & 0.18 & 0.20 & 0.20 \\
\hline Number of observations & 3777 & 4449 & 4449 & 3569 & 3569 \\
\hline Net Housing Wealth & 1995 Survey Data & 1999 Sur & & 2002 Sun & \\
\hline $\mathrm{HH}$ head party member & $\overline{1106^{* *}}$ & $7575^{\star \star \star}$ & $7371^{\star \star \star}$ & $8470^{\star \star \star}$ & $8175^{\star \star *}$ \\
\hline & $(476)$ & $(1270)$ & $(1212)$ & $(2466)$ & $(2439)$ \\
\hline Spouse party member & 539 & $5683^{* \star \star}$ & $5575^{\star \star \star}$ & $7859^{\star \star \star}$ & $7552^{* \star *}$ \\
\hline & $(589)$ & (1643) & $(1590)$ & (3007) & (3005) \\
\hline Father party member & & & $2231^{*}$ & & $5292^{\star \star}$ \\
\hline & & & (1268) & & $(2615)$ \\
\hline $\mathrm{HH}$ head years of schooling & -155 & $975^{\star * \star}$ & $966^{\star \star *}$ & $1787^{\star \star \star}$ & $1739^{* \star *}$ \\
\hline & $(75)$ & $(206)$ & $(211)$ & $(365)$ & (393) \\
\hline Spouse years of schooling & -106 & $434^{* * *}$ & $430^{* * *}$ & $1749^{* \star \star}$ & $1724^{* \star *}$ \\
\hline & $(60)$ & (167) & $(161)$ & (298) & (333) \\
\hline $\mathrm{HH}$ head age & 35 & $389^{* * *}$ & $420^{* \star *}$ & $774^{* \star *}$ & $831^{\star \star \star}$ \\
\hline & $(71)$ & $(167)$ & $(170)$ & $(107)$ & $(102)$ \\
\hline $\mathrm{HH}$ head gender & $1707^{\star \star *}$ & -1282 & -1224 & -3551 & -3410 \\
\hline & $(442)$ & (1232) & (1259) & $(2296)$ & $(2310)$ \\
\hline Number of adult memb (16-65) & $798^{\star \star \star}$ & $1496^{* *}$ & $1552^{*}$ & $4513^{\star \star \star}$ & $4621^{* * *}$ \\
\hline & (295) & $(726)$ & $(807)$ & $(1387)$ & (1389) \\
\hline Adjusted $\mathrm{R}^{2}$ & 0.05 & 0.07 & 0.07 & 0.14 & 0.14 \\
\hline Number of observations & 3777 & 444928 & 4449 & 3569 & 3569 \\
\hline
\end{tabular}


Table 6: Impact of party membership on housing acquisition

\begin{tabular}{|c|c|c|c|c|c|c|}
\hline & \multicolumn{4}{|c|}{ Housing size and quality, pre-housing reform } & \multicolumn{2}{|c|}{ Purchasing price subsidy } \\
\hline & $\begin{array}{l}\text { Log(housing area) } \\
1988\end{array}$ & $\begin{array}{l}\text { Log(housing area) } \\
1995\end{array}$ & $\begin{array}{l}\text { Housing quality } \\
1988\end{array}$ & $\begin{array}{l}\text { Housing quality } \\
1995\end{array}$ & $\begin{array}{l}\text { Log(market price- } \\
\text { price paid) } 1999\end{array}$ & $\begin{array}{l}\text { Log(market price- } \\
\text { price paid) } 2002\end{array}$ \\
\hline & (1) & (2) & 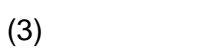 & (4) & (5) & (6) \\
\hline $\mathrm{HH}$ head party member & $\begin{array}{l}0.062 \\
(0.014)^{\star \star \star}\end{array}$ & $\begin{array}{l}0.071 \\
(0.019)^{\star \star \star}\end{array}$ & $\begin{array}{l}0.070 \\
(0.044)\end{array}$ & $\begin{array}{l}0.030 \\
(0.068)\end{array}$ & $\begin{array}{l}0.134 \\
(0.033)^{\star \star \star}\end{array}$ & $\begin{array}{l}0.098 \\
(0.035)^{\star \star \star}\end{array}$ \\
\hline Spouse party member & $\begin{array}{l}0.086 \\
(0.019)^{\star \star \star}\end{array}$ & $\begin{array}{l}0.057 \\
(0.023)^{\star \star}\end{array}$ & $\begin{array}{l}0.171 \\
(0.059)^{\star \star \star}\end{array}$ & $\begin{array}{l}0.239 \\
(0.078)^{\star \star \star}\end{array}$ & $\begin{array}{l}0.091 \\
(0.037)^{\star \star}\end{array}$ & $\begin{array}{l}0.068 \\
(0.034)^{\star \star}\end{array}$ \\
\hline $\mathrm{HH}$ head gender & $\begin{array}{l}-0.035 \\
(0.029)\end{array}$ & $\begin{array}{l}-0.025 \\
(0.019)\end{array}$ & $\begin{array}{l}-0.036 \\
(0.096)\end{array}$ & $\begin{array}{l}-0.202 \\
(0.067)^{\star \star \star}\end{array}$ & $\begin{array}{l}-0.018 \\
(0.038)\end{array}$ & $\begin{array}{l}-0.018 \\
(0.037)\end{array}$ \\
\hline $\mathrm{HH}$ head age & $\begin{array}{l}0.018 \\
(0.005)^{\star \star \star}\end{array}$ & $\begin{array}{l}0.031 \\
(0.006)^{\star \star \star}\end{array}$ & $\begin{array}{l}0.030 \\
(0.016)^{\star}\end{array}$ & $\begin{array}{l}0.086 \\
(0.020)^{\star \star \star}\end{array}$ & $\begin{array}{l}0.008 \\
-0.01\end{array}$ & $\begin{array}{l}0.004 \\
-0.011\end{array}$ \\
\hline $\mathrm{HH}$ head $\mathrm{age}^{2} / 100$ & $\begin{array}{l}-0.008 \\
(0.005)\end{array}$ & $\begin{array}{l}-0.021 \\
(0.006)^{\star \star \star}\end{array}$ & $\begin{array}{l}-0.015 \\
(0.017)\end{array}$ & $\begin{array}{l}-0.068 \\
(0.020)^{\star \star \star}\end{array}$ & $\begin{array}{l}0.001 \\
(0.010)\end{array}$ & $\begin{array}{l}0.007 \\
(0.011)\end{array}$ \\
\hline $\mathrm{HH}$ head years of schooling & $\begin{array}{l}0.010 \\
(0.002)^{\star \star \star}\end{array}$ & $\begin{array}{l}0.009 \\
(0.003)^{\star \star \star}\end{array}$ & $\begin{array}{l}0.035 \\
(0.007)^{\star \star \star}\end{array}$ & $\begin{array}{l}0.024 \\
(0.010)^{\star \star}\end{array}$ & $\begin{array}{l}0.006 \\
(0.005)\end{array}$ & $\begin{array}{l}0.023 \\
(0.006)^{\star \star \star}\end{array}$ \\
\hline Spouse years of schooling & $\begin{array}{l}0.001 \\
(0.002)\end{array}$ & $\begin{array}{l}0.004 \\
(0.003)\end{array}$ & $\begin{array}{l}0.042 \\
(0.007)^{\star \star \star}\end{array}$ & $\begin{array}{l}0.031 \\
(0.010)^{\star \star \star}\end{array}$ & $\begin{array}{l}0.007 \\
(0.006)\end{array}$ & $\begin{array}{l}0.012 \\
(0.006)^{\star \star}\end{array}$ \\
\hline $\mathrm{HH}$ head is a managerial staff & $\begin{array}{l}0.113 \\
(0.021)^{\star \star \star}\end{array}$ & $\begin{array}{l}0.113 \\
(0.024)^{\star \star \star}\end{array}$ & $\begin{array}{l}0.098 \\
-0.063\end{array}$ & $\begin{array}{l}0.360 \\
(0.080)^{\star \star \star}\end{array}$ & $\begin{array}{l}0.151 \\
(0.034)^{\star \star \star}\end{array}$ & $\begin{array}{l}0.113 \\
(0.053)^{\star \star}\end{array}$ \\
\hline Spouse is a managerial staff & $\begin{array}{l}0.008 \\
(0.043)\end{array}$ & $\begin{array}{l}0.065 \\
(0.030)^{\star \star}\end{array}$ & $\begin{array}{l}-0.047 \\
(0.138)\end{array}$ & $\begin{array}{l}0.072 \\
(0.106)\end{array}$ & $\begin{array}{l}0.055 \\
(0.049)\end{array}$ & $\begin{array}{l}0.043 \\
(0.070)\end{array}$ \\
\hline Household size & $\begin{array}{l}0.105 \\
(0.007)^{\star \star \star}\end{array}$ & $\begin{array}{l}0.086 \\
(0.011)^{\star \star \star}\end{array}$ & $\begin{array}{l}0.001 \\
(0.023)\end{array}$ & $\begin{array}{l}0.025 \\
(0.038)\end{array}$ & $\begin{array}{l}0.078 \\
(0.018)^{\star \star \star}\end{array}$ & $\begin{array}{l}0.027 \\
(0.020)\end{array}$ \\
\hline Years since bought the house & & & & & $\begin{array}{l}0.026 \\
(0.015)^{\star}\end{array}$ & $\begin{array}{l}0.047 \\
(0.021)^{\star \star}\end{array}$ \\
\hline Years since bought the house ${ }^{2}$ & & & & & $\begin{array}{l}-0.002 \\
(0.002)\end{array}$ & $\begin{array}{l}-0.005 \\
(0.002)^{\star \star}\end{array}$ \\
\hline Region & Yes & Yes & Yes & Yes & Yes & Yes \\
\hline Observations & 3022 & 2166 & 3034 & 2167 & 2178 & 2083 \\
\hline R-squared & 0.37 & 0.21 & 0.29 & 0.15 & 0.43 & 0.38 \\
\hline
\end{tabular}

Standard errors in parentheses

* significant at 10\%; ** significant at $5 \%$; ** significant at $1 \%$ 
Figure 1: Cumulative Density Functions of different type of wealth
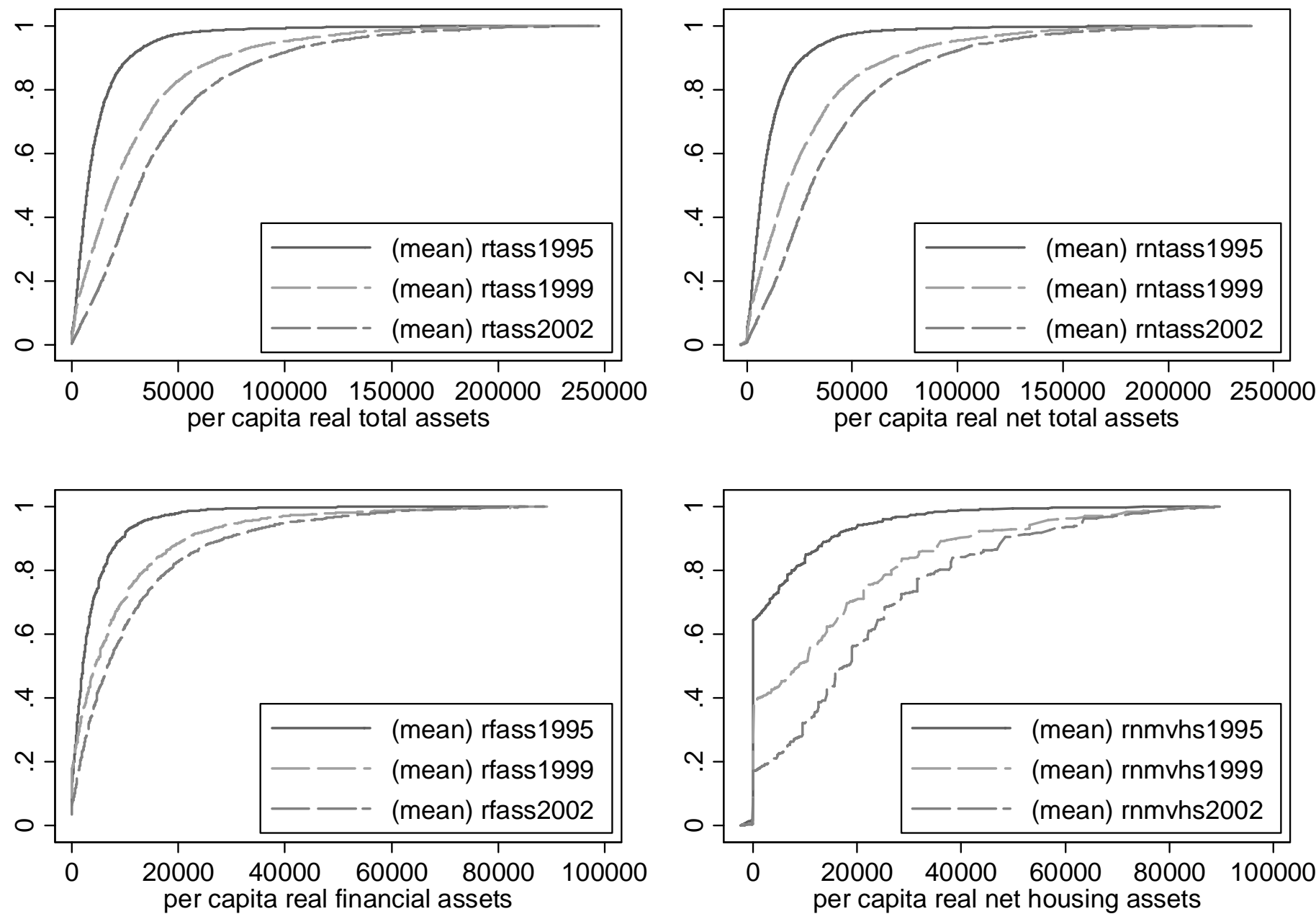
Figure 2: Lorenz curves of different type of wealth
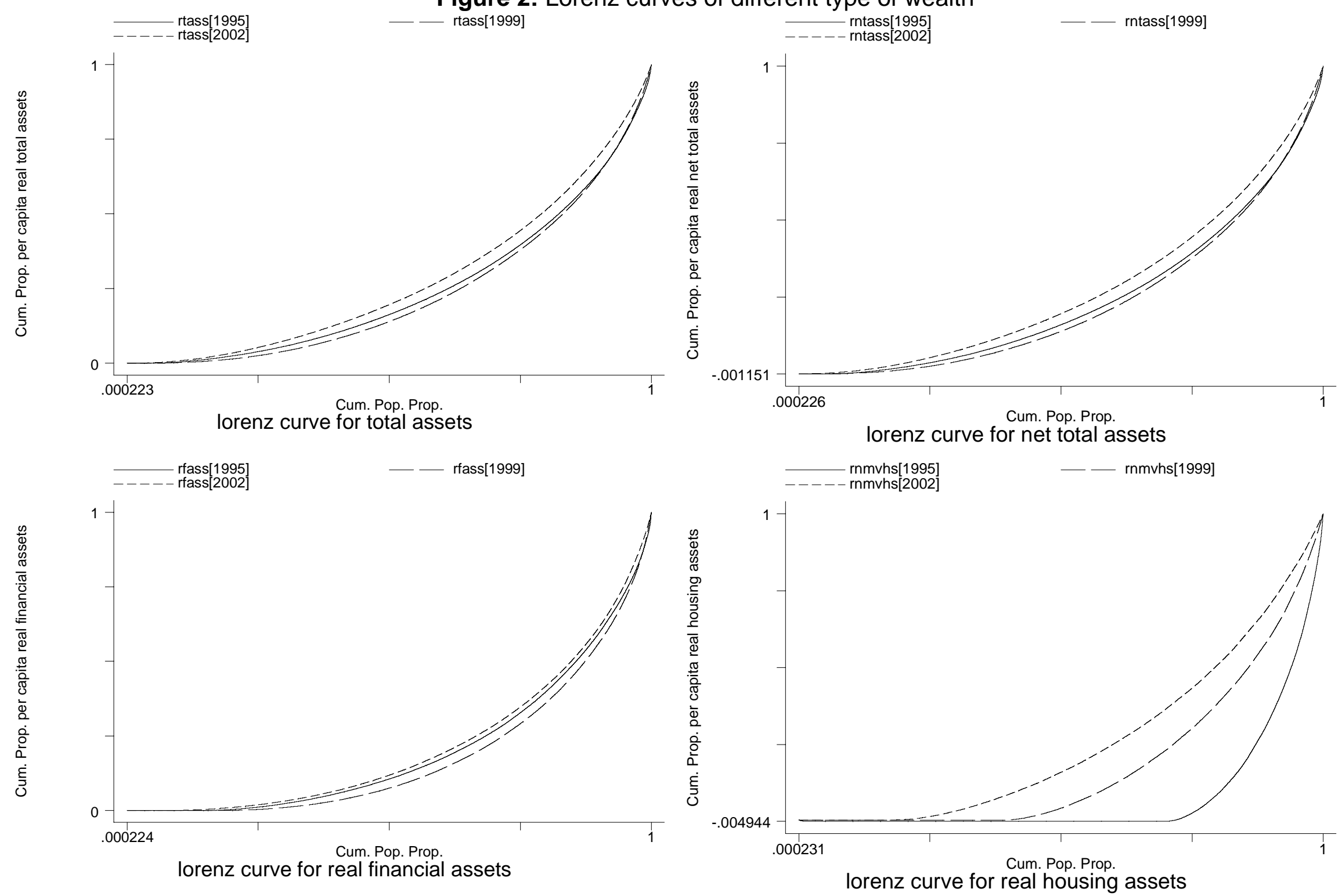
Figure 3: Net wealth distribution by percentile of household per capita income

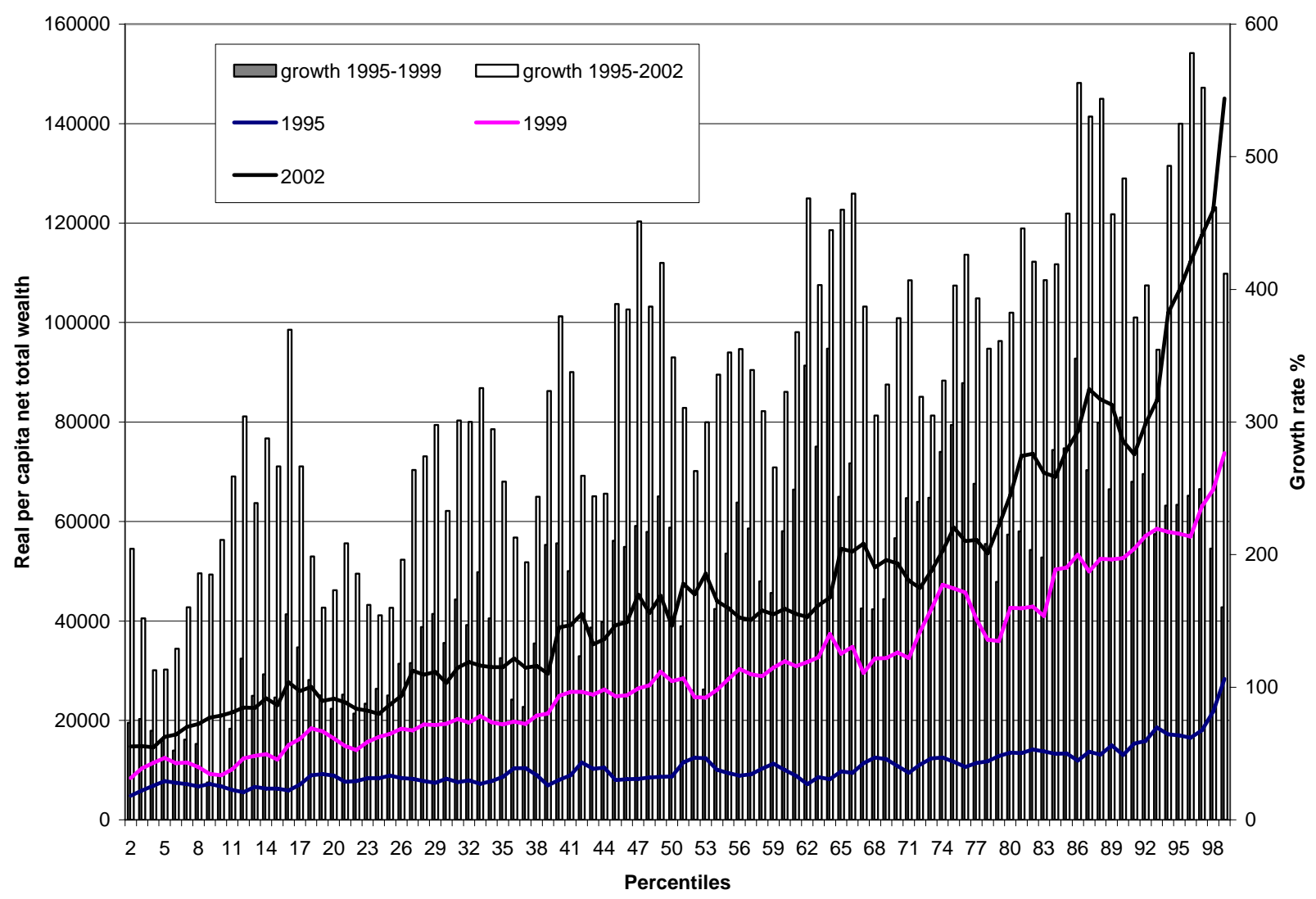


Figure 4: Actual and predicted net total wealth by income percentile 1995-1999

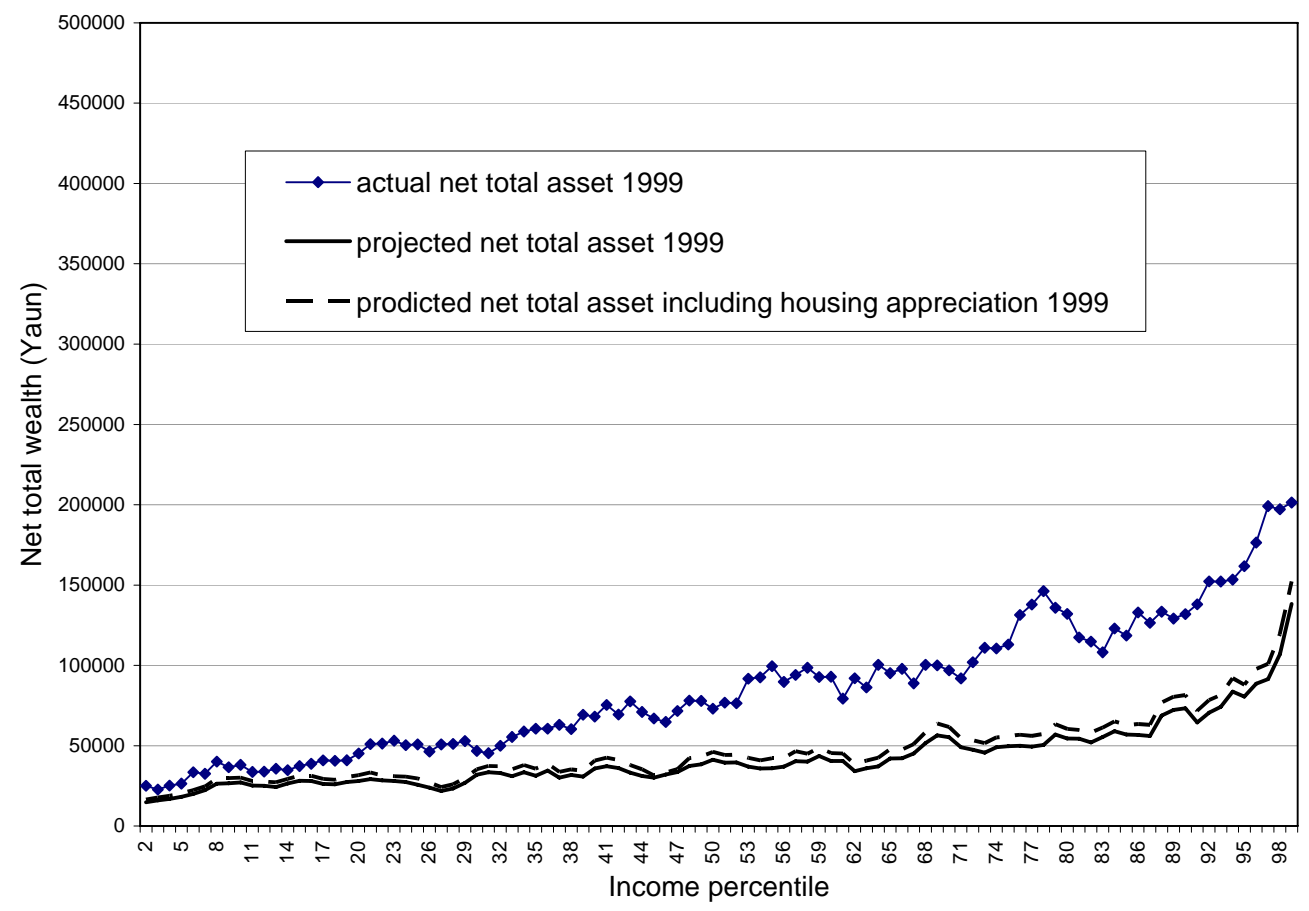

1995-2002

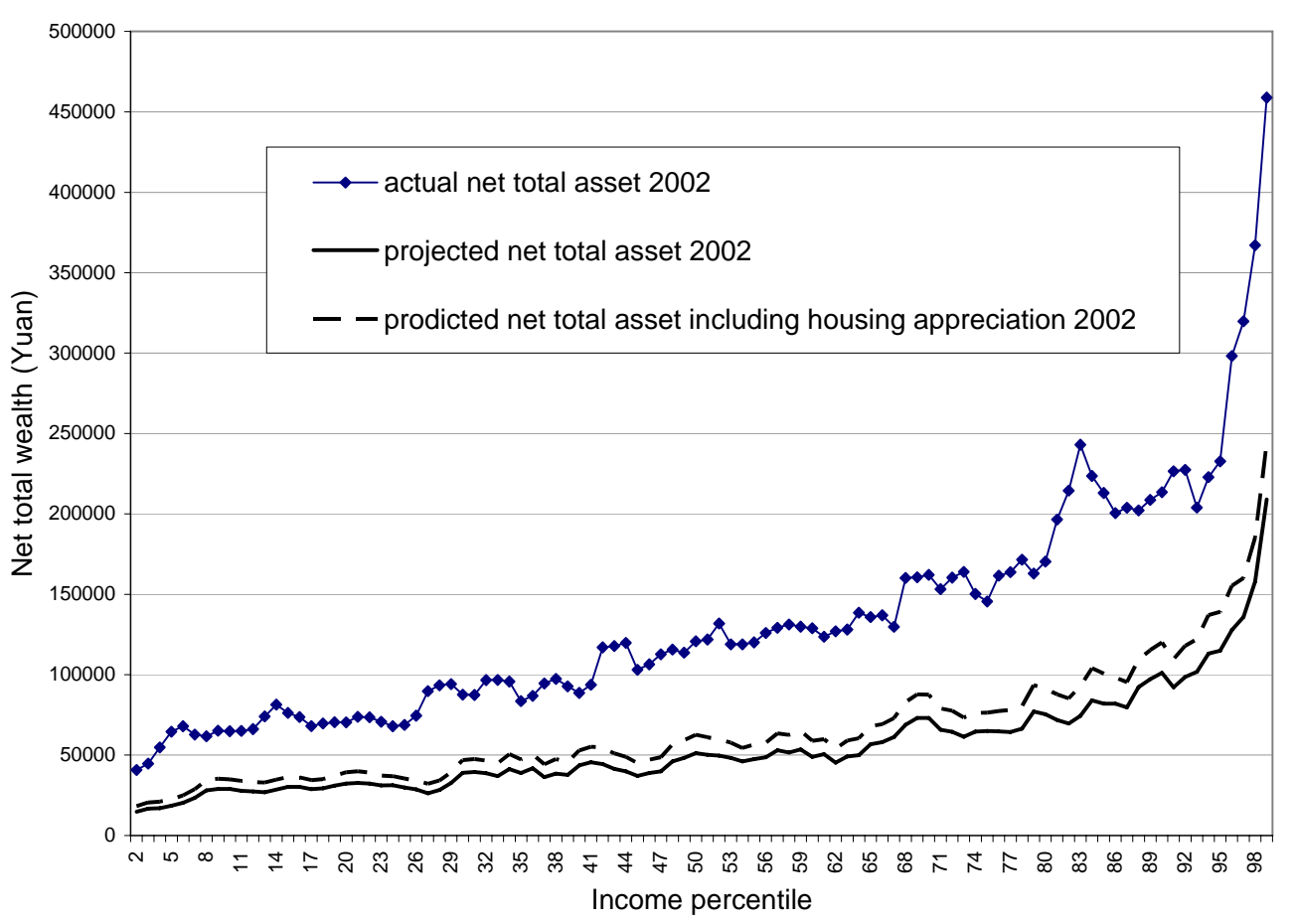


Figure 5: Wealth-Age Profile, 1995, 1999, and 2002

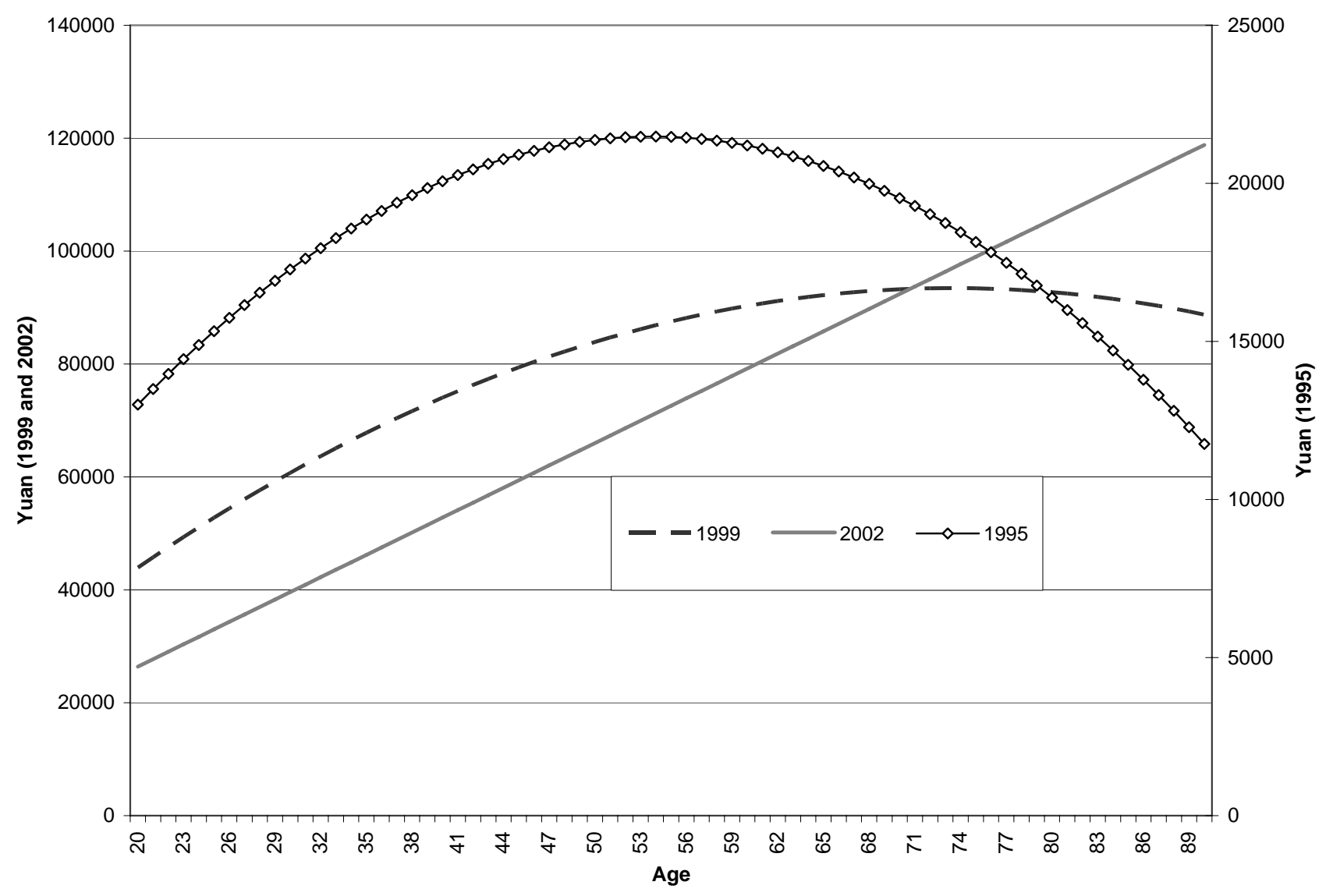




\section{Appendix A: Summary Statistics}

\begin{tabular}{|c|c|c|c|c|c|c|}
\hline \multirow[b]{2}{*}{ Variable } & \multicolumn{2}{|c|}{1995 Survey } & \multicolumn{2}{|c|}{1999 Survey } & \multicolumn{2}{|c|}{2002 Survey } \\
\hline & Mean & Std. Dev. & Mean & Std. Dev. & Mean & Std. Dev. \\
\hline Real per capita net total wealth & 10641 & 14200 & 30341 & 38199 & 48621 & 63022 \\
\hline Real per capita financial wealth & 3902 & 6806 & 9183 & 14371 & 14437 & 31539 \\
\hline Real per capita net housing wealth & 3552 & 9425 & 17790 & 29593 & 29823 & 47515 \\
\hline $\mathrm{HH}$ head's father is a party member & & & 0.26 & & 0.27 & \\
\hline $\mathrm{HH}$ head is a party member & 0.33 & & 0.37 & & 0.37 & \\
\hline Spouse is a party member & 0.20 & & 0.20 & & 0.22 & \\
\hline HH head years of schooling & 10.49 & 3.30 & 10.62 & 3.13 & 10.63 & 3.28 \\
\hline Spouse years of schooling & 9.08 & 4.17 & 9.22 & 4.22 & 9.46 & 4.13 \\
\hline HH head age & 46.45 & 11.49 & 47.78 & 11.88 & 49.19 & 11.37 \\
\hline HH head gender & 0.66 & & 0.67 & & 0.70 & \\
\hline Number of working aged members & 2.15 & 0.78 & 2.06 & 0.82 & 1.87 & 0.80 \\
\hline Beijing & 0.13 & & 0.15 & & 0.14 & \\
\hline Liaoning & 0.18 & & 0.16 & & 0.20 & \\
\hline Jiangsui & 0.21 & & 0.16 & & 0.20 & \\
\hline Henan & 0.16 & & 0.18 & & 0.19 & \\
\hline Sichuan & 0.22 & & 0.20 & & 0.16 & \\
\hline Gansu & 0.11 & & 0.15 & & 0.11 & \\
\hline Number of observations & 3777 & & 4449 & & 3570 & \\
\hline \multicolumn{7}{|c|}{ Party membership distribution among different survey years and for different surveys } \\
\hline UHIDS: & \multicolumn{2}{|c|}{1995 Survey } & \multirow{2}{*}{\multicolumn{2}{|c|}{$\frac{1999 \text { Survey }}{2067}$}} & \multicolumn{2}{|c|}{2002 Survey } \\
\hline Total sample & \multicolumn{2}{|c|}{18.38} & & & \multicolumn{2}{|c|}{21.20} \\
\hline Aged 18 and above & \multicolumn{2}{|l|}{23.38} & 20.67 & 24.90 & \multicolumn{2}{|l|}{25.54} \\
\hline of which: Males & \multicolumn{2}{|l|}{33.07} & \multicolumn{2}{|l|}{33.18} & \multicolumn{2}{|l|}{34.01} \\
\hline Females & \multicolumn{2}{|l|}{13.95} & \multicolumn{2}{|l|}{16.84} & \multicolumn{2}{|l|}{17.63} \\
\hline CULS: 2000 & & & \multirow{2}{*}{\multicolumn{4}{|c|}{2000 Survey }} \\
\hline Aged 18 and above & \multirow{2}{*}{\multicolumn{6}{|c|}{$\begin{array}{l}20.56 \\
28.03\end{array}$}} \\
\hline of which: Males & & & & & & \\
\hline Females & \multicolumn{6}{|c|}{13.59} \\
\hline
\end{tabular}




\section{Appendix B: Housing price changes, 1995, 1999, 2002}

\begin{tabular}{|c|c|c|c|c|c|c|}
\hline & & & \multicolumn{2}{|c|}{ Change } & Change & Change \\
\hline Official data ${ }^{a}$ & 1995 & 1999 & \multicolumn{2}{|c|}{2002 1999-2002 } & 1995-1999 & 1995-2002 \\
\hline Beijing & 3413 & 4787 & 4467 & 0.93 & 1.40 & 1.31 \\
\hline Liaoning & 1446 & 1754 & 1991 & 1.14 & 1.21 & 1.38 \\
\hline Jiangsu & 1247 & 1461 & 1806 & 1.24 & 1.17 & 1.45 \\
\hline Henan & 431 & 959 & 1291 & 1.35 & 2.23 & 3.00 \\
\hline Sichuan & 1029 & 1163 & 1190 & 1.02 & 1.13 & 1.16 \\
\hline Gansu & 1148 & 1062 & 1195 & 1.12 & 0.93 & 1.04 \\
\hline \multirow[t]{2}{*}{ Simple average of six provinces } & 1452 & 1864 & 1990 & 1.07 & 1.28 & 1.37 \\
\hline & & & \multicolumn{2}{|c|}{ Change } & Change & Change \\
\hline Survey data ${ }^{b}$ & $1995^{\mathrm{C}}$ & 1999 & \multicolumn{2}{|c|}{2002 1999-2002 } & 1995-1999 & $1995-2002$ \\
\hline Beijing & & 4593 & 4885 & 1.06 & & \\
\hline Liaoning & & 1656 & 1759 & 1.06 & & \\
\hline Jiangsu & & 2198 & 1603 & 0.73 & & \\
\hline Henan & & 806 & 794 & 0.99 & & \\
\hline Sichuan & & 1015 & 867 & 0.85 & & \\
\hline Gansu & & 967 & 1001 & 1.03 & & \\
\hline Simple average of six provinces & & 1873 & 1818 & 0.97 & & \\
\hline
\end{tabular}

Sources: a. Data obtained from Table 5-35 on page 188, the China Statistical Yearbook, 1996; Table 6-44 on page 225 of the China Statistical Yearbook, 2000; and Table 6-45 on page 245, the China Statistical Yearbook, 2003. b. data obtained from 1999 and 2002 household surveys. c. The 1995 survey did not ask the estimated market value of owner occupied housing. 


\section{Appendix C: Residual distributions}
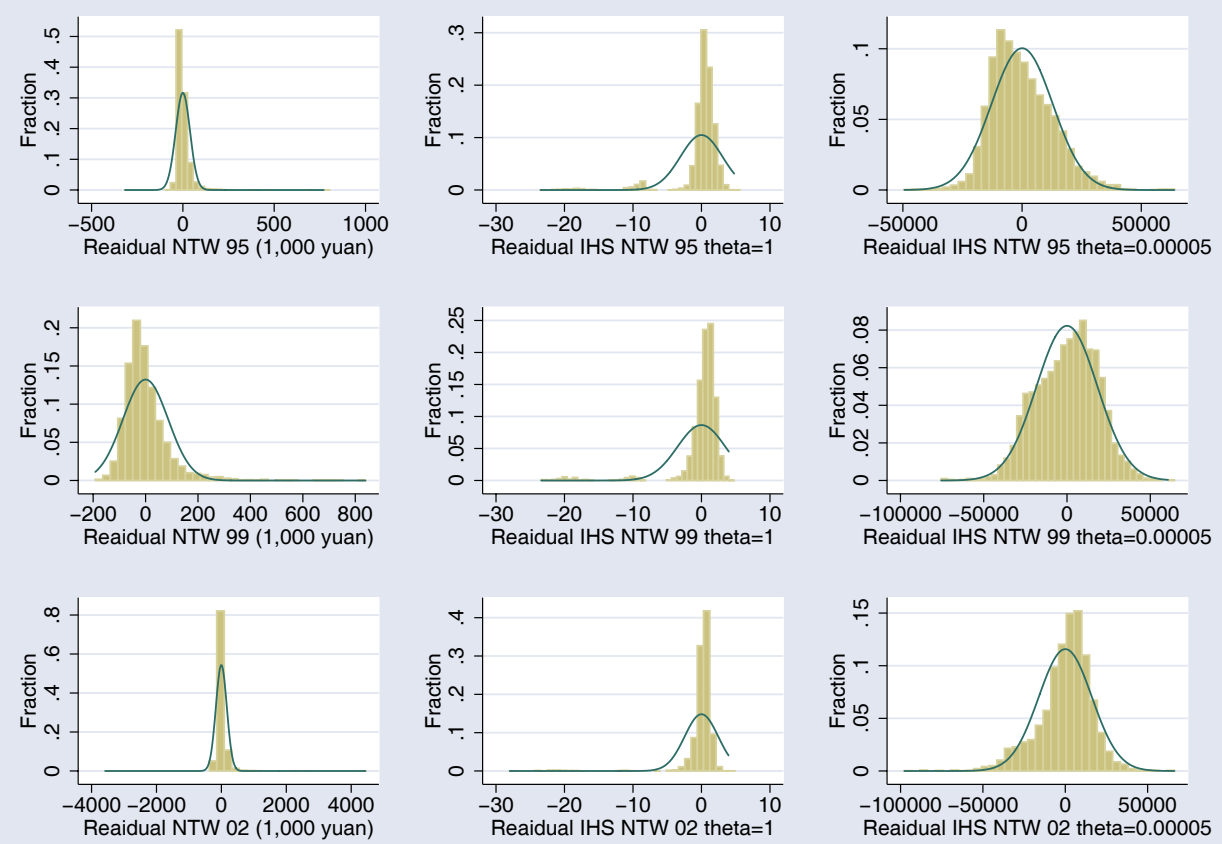

Figure 1: Residual distribution net total wealth and Inverse hyperbolic sine transformation (theta $=1$ or theta $=0.00005), 1995,1999$, and 2002 


\begin{tabular}{lll}
$\begin{array}{l}\text { Appendix D: Selected results from housing market value } \\
\text { equation }\end{array}$ & \\
\hline \hline & 1999 & 2002 \\
Housing area $\left(\mathrm{M}^{2}\right)$ & 1,473 & 1,936 \\
& $(109)^{\star \star \star}$ & $(148)^{\star \star \star}$ \\
With central gas cooking & 11,542 & 25,735 \\
With central heating & $(3,371)^{\star \star \star}$ & $(3,153)^{\star \star \star}$ \\
With both bathroom and toilet & 7,591 & 9,216 \\
& $(3,264)^{\star \star}$ & $(3,032)^{\star \star \star}$ \\
With own kitchen & 5,198 & $-1,336$ \\
& $(3,134)^{\star}$ & $(3617)$ \\
Located in the city & $-2,467$ & 3,349 \\
& $(5136)$ & $(8015)$ \\
Townhouse or flat with full facilities & 22,799 & $-12,483$ \\
& $(3,218)^{\star \star \star}$ & $(5,633)^{\star \star}$ \\
Region & -569 & 21,198 \\
Observations & $(3062)$ & $(4,631)^{\star \star \star}$ \\
R-squared & Yes & Yes \\
\hline \hline Robs sand & 2547 & 2394 \\
\hline
\end{tabular}

Robust standard errors in parentheses

* significant at 10\%; ** significant at $5 \%$; ** significant at $1 \%$ 